\title{
DEVELOPING NEW EGYPTIAN LOCAL LINES OF TOMATO (SOLANUM LYCOPERSICUM L.)
}

\author{
M.F. Ahmed*, H.A.Hamza, I. A. Ibrahim, A .A. Nower and M. Alansary \\ Plant Biotechnology Department, Genetic Engineering and Biotechnology Research Institute, \\ University of Sadat City, Egypt. \\ Corresponding author*. Email: mosaad.fawzy@gmail.com
}

Received: May 18, 2016

Accepted: Nov. 9,2016

\begin{abstract}
A study was conducted at Zifta district, Gharbia governorate, at middle delta region of Egypt during seven successive seasons of 2009-2015 to study the genetic variability and heritability for some plant and fruit characteristics in tomato. Fifteen F7 lines were selected from 4 F2 generations of six generations of selection. The estimated coefficient of variance (C.V $\%$ values (degree of homogeneity) differed among the studied genotypes for the same character and from trait to another of the same genotype. The selected genotypes were enough homogenous for the studied traits and then it could be considered as new lines. A great diversity and significant differences were observed among the fifteen selected genotypes for all studied traits. The lines S.209, K.111-1, K.111-6, AL. 3-1-3 and EUR. 2-2 were considered the best lines for yield and fruit quality traits, and could be used in breeding programs to develop new local F1 hybrids of tomato.

The results showed high values for genotypic coefficient of variation (G.C.V \%) compared with the phenotypic coefficient of variation (P.C.V \%) and high heritability in broad sense ( $\left.h^{2} b s\right)$ for all studied traits. The G.V.C\% vs P.C.V\% and ( $\left.h^{2} b s\right)$ values were 18.43 vs $22.08 \%$ and 0.70 for (days to 50\% flowering), 20.09 vs 22.46 and 0.8 (for plant height ),22.94 vs 24.80 and 0.86 ( for number of branches ), 16.67 vs 17.26 and 0.93 (for early yield), 18.25 vs 18.53 and 0.94 (for total yield), 16.59 vs 19.22 and 0.75 (for fruit firmness), indicating small environmental effects and large additive genetic components of the phenotypic variation for these traits and can be improved through selection programs.
\end{abstract}

Key words: Tomato breeding, genotypes, local varieties.

\section{INTRODUCTION}

Tomato (Solanum lycopersicum L.) is the most important vegetable crop grown for human consumption. Since the modern cultivars often have higher crop indices than the older outmoded ones (Holiday, 1976), attention must be given to development of new high yielding lines through breeding programs. The breeder hopes to find plants in F2 that combine the desired levels of expression. Maximum progress in improving a character would be expected with a carefully designed pedigree selection program, when the additive gene action is the main component of gene effects. Many studies reported that, the additive genetic variance was more important than non-additive ones for most tomatoe traits, among them were Metwally et al., (1996), Thakur and Kohli, (2005), Saeed et al., ( 2008), Shahabuddin et al., (2009), Salib (2012), and Kansouh (2013 \& 2014), for number of plant branches, average fruit weight and fruit firmness. According to Bhatt et al., (2001), Hannan et al., (2007) Singh et al., (2007), Sekhar et al., (2010) and Kansouh (2013), the magnitude of additive and non-additive variance was significant and approximately play the same role in the inheritance of tomato early and total yield.

A close correspondence between genotypic coefficient of variation (G.C.V\%) and phenotypic coefficient of variation (P.C.V\%)varies with high values of broad sense heritability $\left(h^{2} b\right)$ previously reported 
Ahmed, et al.,

by Asati et al., (2008), Anjum Ara et al., (2009), Surma et al., (2009), Kansouh and Zakher (2011), Ahirwar et al., (2013), and Kansouh (2013), for plant height, number of branches, early and total yield, average fruit weight and total soluble solids (TSS\%) content.

Selection is an important methods for improving characters, especially in selfpollinated crops, Berry and Rafique (1988), selected F3 and F4 lines of tomato adapted to high temperature from different origins. Kansouh (2002), developed high yielding lines of tomato by selection from $3 \mathrm{~F} 2$ populations. Also, Islam et al., (2011), selected segregating tomato lines and evaluated them to develop high yield and virus resistant varieties. The main objective of this study was to develop a new promising local lines of tomato by selection and estimating the extent of variability and dividing that variabilities into heritable and non-heritable components in the selected lines.

\section{MATERIALS AND METHODS}

This study was carried out at the growing farmers of Zifta districts, Gharbia governorate, Middle delta region during the successive summer seasons of 2009 till 2015. Seeds of $4 \mathrm{~F} 2$ populations of tomato (Solanum lycopersicum L.) were developed and used for this study. In season of 2009, 300 plants from each of the four populations were grown, the best 28 plants were selected and seeds were separately collected. In the season of 2010 , a number of 100 plants from the progeny of each selected plant were planted. Observations and selection were made between and within the F3 families, in order to select the best plants with the best fruit characters. Nine families were excluded according to preliminary observations, seeds of the best plant from each remained family were separately collected as F4. The planting, observation and selection were continued during the seasons of 2011 and 2012, in order to obtain seeds of the F6 generation.
In the season of 2013 , sixty plants with three replicates (20 plants/plot) of the F6 populations representing 19 selected genotypes were grown with the commercial cv. Super strain B and Allisa F1 Hybrid (as check cvs). The coefficient of Variance (C.V $\%$ ) was estimated for all selected genotypes concerning some characters (days of flowering, plant height, fruit shape, fruit firmness and total soluble solids TSS\% content) to determine the degree of its homogeneity. At the same time data for some plant and fruit characteristics were recorded. According to the obtained data, five populations were excluded due to their high heterogeneity (C.V \%). The remaining 14 genotypes, in addition to the line S.2 (which chosen from a breeding program conducted by Kansouh 2002), were evaluated again with the check cultivar Supper strain B. the seedlings were transplanted on February $15^{\text {th }}$ in all seasons of the experiments. A randomized complete block design with three replicates was used. The plants were spaced at $40 \mathrm{~cm}$ apart on rows, $125 \mathrm{~cm}$ wide between rows, and 500 $\mathrm{cm}$ long. Routine cultural practices were similar to farmers' conditions in tomato commercial production.

Data were recorded for the following characters, number of days from transplanting to flowering of $50 \%$ of plants, plant height $(\mathrm{cm})$ and number of primary branches /plant at the end of flowering stage, early yield ( $\mathrm{kg} / \mathrm{plant}$ ) as yield of first three harvests, total yield (kg/plant) as total weight of all harvested fruits, average fruit weight, fruit firmness $(\mathrm{g} / \mathrm{cm}$ ) (measured by using a needle type pocket penetrometer ), and fruit shape index (estimated by dividing fruit length on fruit diameter) and described to UPOV guide 1992). Analysis of variance, component of variance (coefficient of variance, C.V\%, genotypic and phenotypic coefficient of variance, G.C.V\% and P.C.V $\%)$ and broad sense heritability $\left(h^{2} b\right)$ were estimated as reported by Singh and Chaudhary (1995). 


\section{Developing new Egyptian local lines of tomato (Solanum lycopersicum L.)}

\section{RESULTS AND DISCUSSION}

\section{Degree of homogeneity:}

Estimated coefficient of variance (C.V\%) values for number of days from transplanting to $50 \%$ flowering of plants (Table 1 ) showed that, the selected genotypes PPP.1-2, ROC.1,ROC.1-2-3, SQ. 5, and DUS. 7-4-1 recorded C.V \% values higher than those of the check cultivars Alissa F1 hybrid and supper strain B , indicating high heterogeneity $(C . V \%>7.00)$, the remaining selected genotypes become higher homogenous for this trait, since they reflected C.V \% values close to or lower than those of the check cvs. Supper strain B, and Alissa F1 hybrid. However, the genotype of EUR. 2-2, ROC.2 and GAP-16 showed the lowest C.V\% values, i.e. 3.87, 3.91 and $3.87 \%$ respectively, indicating that they are more uniform than other genotypes or check varieties.

Plant height, estimated coefficient of variance (C.V \%) values (Table 1) ranged from 3.10 , to $13.57 \%$ in the selected genotypes, compared with 5.12 and 7.33 in the check cultivars. (Super strain B and Alissa F1 hybrid). The genotypes PET-8, AL -3B, STA 12-10, SMA-12 and GAP-16 could be considered the highest homogenous for this trait, since they gave the lowest variation values $(\mathrm{C} . \mathrm{V} \%<5.00)$. On the other hand, the lowest homogeneity were observed in the genotypes ROC, 1-2-3 and DUS. 7-4-1, where they gave the highest C.V \% values (11.65 and $13.75 \%$, respectively). However, except the four genotypes PPP.1-2, RDC.1, ROC.1-2-3 and DUS 7-4-1. All lines became high homogeneous in this trait, since they gave C.V \% values close or lower than the commercial Super strain B and Alissa F1 hybrid .

Concerning fruit shape index, data listed in (Table 1), showed that, the highest homogeneity was observed in the genotypes, K111-6, and GAP-16, since they gave the lowest C.V \% values $(6.13$ and $5.67 \%$, respectively), while, plants of the four genotypes ROC. 1, ROC. 1-2-3, SQ5 and DUS. 7-4-1 showed the highest heterogeneity, since they recorded the highest C.V\% values (C.V\% >10.00). However, except those previous four genotypes, the C.V \% values of new breeding lines were lower than those of the check cultivars (Super strain B, and Alissa F1 hybrid), indicating high homogeneity for this trait,

Regarding fruit firmness, the genotypes ROC.1 and PET-8 could be considered the highest homogenous, since they reflected the lowest variation (C.V\% were 4.01 and $3.67 \%$ respectively), while the highest heterogeneity was observed for the genotype ROC.1-2-3, (C.V\% = 8.57\%). However, except the five genotypes which showed C.V \% more than 5\%, all selected genotypes became highly homogeneous for this trait, since they reflected C.V \% values lower than that of the check cultivar Supper strain B.

For total soluble solids content (TSS\%), results showed that the lowest C.V \% values, i.e., $8.15,8.93$ and $9.01 \%$ were recorded by the genotypes S.209, ROC. 2 and GAP.16, respectively, indicating that they were more uniform than other genotypes. In this respect, except the five genotypes PPP1-2, ROC-1 ROC.1-2-3, SQ5 and DUS. 7-4-1 which showed C.V \% values higher than $12.00 \%$ (high heterogeneity )the remaining selected genotypes showed high homogeneity for this trait, since they reflected C.V\% values close to or lower than those of check variety Super strain B, and Alissa F1 hybrid.

Generally, the degree of homogeneity (C.V \%) differed among the studied genotypes for the same character and from trait to another in the same genotype. Also, obtained coefficient of variance (C.V\%) values for studied traits showed that the genotypes PPP1-2, ROC.1, ROC1-2-3, SQ.5 and DUS 7-4-1 reflected the highest C.V \% values compared to those given by the check cultivar Super strain B and Alissa 
Ahmed, et al.,

F1 hybrid for most traits, indicating high heterogeneity, so they were excluded. The remaining 14 selected genotypes are enough homogenous, since they showed C.V\% values near or lower than those of the two check varieties, then it could be considered as new lines. These results are in agreement with those of Berry and Rafique (1988), Kansouh (2002), and Islam et al., (2011), who selected many lines of tomato from F2, F3, and F4 generations and reported that the selected lines became higher in homogeneity after F6 generation.

Table (1): Estimated coefficient of variance (C.V \%) values for five studied characters in the selected estimated genotypes.

\begin{tabular}{|c|c|c|c|c|c|}
\hline Genotypes & Days of flowering & $\begin{array}{c}\text { Plant height } \\
\mathrm{cm} .\end{array}$ & $\begin{array}{c}\text { Fruit Shape } \\
\text { index }\end{array}$ & $\begin{array}{l}\text { Fruit Firmness } \\
\qquad \mathrm{g} / \mathrm{cm} .\end{array}$ & TSS $\%$ \\
\hline S.209 & 4.26 & 5.33 & 6.83 & 4.36 & 8.15 \\
\hline PPP.1-2 & 9.63 & 12.1 & 8.01 & 5.13 & 12.82 \\
\hline ROC-1 & 7.53 & 8.33 & 13.25 & 4.01 & 14.57 \\
\hline ROC. 1-2-3 & 7.67 & 11.65 & 12.86 & 8.57 & 13.86 \\
\hline S.Q-5 & 12.01 & 7.83 & 10.33 & 5.93 & 16.64 \\
\hline PET-8 & 5.12 & 4.11 & 7.51 & 3.67 & 10.33 \\
\hline END-1 & 6 & 6.67 & 8.01 & 4.19 & 9.81 \\
\hline K.111-1 & 4.36 & 5.4 & 7.6 & 4.37 & 10.01 \\
\hline K.111-6 & 5.67 & 5.37 & 6.13 & 5.00 & 9.67 \\
\hline AL.3B & 4.73 & 3.1 & 6.81 & 4.12 & 10.33 \\
\hline AL. 3-1-3 & 5.2 & 6.25 & 7.46 & 4.83 & 10.46 \\
\hline EUR. 2-2 & 3.87 & 5.1 & 7.03 & 4.36 & 9.52 \\
\hline DUS.7-4-1 & 9.13 & 13.57 & 13.56 & 5.10 & 14.5 \\
\hline STA. $12-10$ & 5.10 & 4.02 & 7.14 & 5.00 & 9.67 \\
\hline PO.16-3 & 4.37 & 6.16 & 6.72 & 5.17 & 10.13 \\
\hline L.2 & 6.01 & 5.93 & 6.83 & 4.3 & 9.51 \\
\hline ROC-2 & 3.91 & 5.67 & 7.46 & 4.56 & 8.93 \\
\hline SMA-12 & 4.16 & 4.33 & 8.63 & 4.67 & 9.63 \\
\hline GAP-16 & 3.87 & 4.83 & 5.67 & 4.11 & 9.01 \\
\hline Alissa-F1 hybrid & 4.67 & 5.12 & 7.16 & 3.87 & 9.27 \\
\hline SSB* & 5.83 & 7.33 & 8.67 & 4.63 & 10.13 \\
\hline
\end{tabular}

$\mathrm{SSB}^{\star}$ : The commercial cultivar super strain B as check cv. (control) 


\section{Developing new Egyptian local lines of tomato (Solanum lycopersicum L.)}

\section{П. Mean performance of the selected lines:}

Highly significant differences were observed among the selected lines for all studied traits (Table 2). For number of days to $50 \%$ flowering, it's ranged from 23.17 to 47.5 with a mean of 38.61 days compared to 38.67 days in the check cultivar Super strain $B$. The line GAP-16 could be considered the earliest flowering, since it recorded 23.17 days to $50 \%$ flowering, followed by the lines PET-8, AL-3B, EUR2-2 and PO16-3 where they recorded less than 35.0 days. On the other hand, the latest flowering line were L2 , and ROC-2, since they showed $50 \%$ flowering at 44.28 and 47.5 days, respectively. However, except, the lines GAP-16 and ROC-2 no significant differences between the selected lines and the check cultivar Super strain B were recorded for this trait.

Regarding the plant height, highly significant differences among means of the evaluated lines were observed (Table 2). Their means ranged from $18.25 \mathrm{~cm}$ ( for line GAP-16) to $150.33 \mathrm{~cm}$ ( for line L-2 ) with a mean of $61.92 \mathrm{~cm}$. Compared to the check cultivar Super strain B, five lines ( which showed plant height $>65.0 \mathrm{~cm}$ ) significantly exceeded check cultivar by percentage ranged from $19.18 \%$ ( in the line K-111-6 to $172.49 \%$ for the line L2 ). However eight other lines were statistically similar to the control for this trait.

The highest number of branches per plant (more than 8.0 branches per plant) were recorded for the lines S-209, K-111-1, $\mathrm{K}$ 111-6 and L-2. They significantly exceeded the control by percentages of $26.34 \%, 30.17 \%, 24.81 \%$ and $118.22 \%$, respectively. However, except the line GAP16, which showed the lowest value ( 5.16), the remaining ten lines were statistically similar to the check cultivar Super strain B (Table 2 ).

High significant differences among early yield means of the evaluated lines were observed (Table 2). The recorded early yield ranged from 0.256 to $1.625 \mathrm{Kg} /$ plant. The highest early yield ( more than $1.40 \mathrm{~kg} /$ plant) were produced by the lines S-2, S.209, AL3B, AL-3-1-3,EUR.2-2 and STA 12-10, and significantly exceeded Super strain B (control) by values ranged from $7.78 \%$ ( for line S.209 )to 23.11\% ( for line AL 3-1-3).

Total yield reflected also a great variation among the selected lines evaluated (table 2). The six lines, S.209, K111-1, K111-6, AL 3-1-3, EUR 2-2 and L-2 were considered the best lines since they produced the highest total yield values (more than $6.00 \mathrm{Kg}$ /plant).Also, they exceeded the check cultivar Super strain $B$ by values ranged from $7.21 \%$ ( for line AL 3-1-3) to14.65\% (for the line L-2). On the other hand, the lowest yield value $(0.410 \mathrm{Kg} / \mathrm{plant})$ was observed for the line GAP- 16

Average fruit weight of the selected lines ranged from $15.32 \mathrm{gm}$ to $165.67 \mathrm{gm}$, reflecting significant differences among the studied lines. The heaviest fruit weight (more than $140.0 \mathrm{gm}$ ) was produced by the lines S.209, AL-3B and SMA- 12, while the lightest fruit weight was recorded for the line GAP-16 (15.32gm)

For fruit firmness (Table 2) lines S.209, PET-8, K111-1, K111-6, AL.3B and P016-3 produced the firmest fruits (561.2 to 605.3 $\mathrm{g} / \mathrm{cm}$ ) and statistically similar to the check cultivar Super strain B $(592.7 \mathrm{~g} / \mathrm{cm})$, followed by the lines S.2, AL3-1-3, EUR 2-2 and STA12-10 with values of 512.7 to 542.5 $\mathrm{g} / \mathrm{cm}$. On the other hand, fruits of the lines END-1, L-2, ROC.2, SMA-12, and GAP-16 recorded the lowest firmness values (less than $500 \mathrm{~g} / \mathrm{cm})$.

Generally, According to data obtained, the lines S.209, K111-1, K-111-6, AL.313 and EUR 2-2 were considered the best lines, since they produced the highest total yield with good fruit traits compared to the commercial cultivar Super strain B. It also could be used in breeding programs to develop new local F1 tomato hybrids 
Ahmed, et al.,

adapted to Egyptian environment. Also, our results showed that, pure line selection as a breeding method would be effective for improving yield and fruit characteristics of tomato in Egypt. These results are confirmed with the results obtained by
Kansouh, (2002), Anjum Ara et al., (2009), Islam et al., (2011), and Patel et al., ( 2013), who found significant differences among tomato lines and cultivars studied for the same traits.

Table (2): Mean performances of the evaluated breeding genotypes for some plant and fruit characteristics in tomato.

\begin{tabular}{|c|c|c|c|c|c|c|c|c|c|}
\hline Genc & pes & $\begin{array}{c}\text { Days of } \\
50 \% \\
\text { flowering }\end{array}$ & $\begin{array}{l}\text { Plant } \\
\text { height } \\
\text { (cm.) }\end{array}$ & $\begin{array}{l}\text { Number } \\
\text { of } \\
\text { branches/ } \\
\text { plant }\end{array}$ & $\begin{array}{c}\text { Early } \\
\text { yield } \\
\text { (kg/ } \\
\text { plant) }\end{array}$ & $\begin{array}{c}\text { Total } \\
\text { yield } \\
\text { (kg/plant) }\end{array}$ & $\begin{array}{l}\text { Average } \\
\text { fruit } \\
\text { weight } \\
\text { (g) }\end{array}$ & $\begin{array}{c}\text { Fruit } \\
\text { Firmness } \\
\text { (g/cm.) }\end{array}$ & $\begin{array}{l}\text { Fruit } \\
\text { Shape }\end{array}$ \\
\hline & & 37.14 & 57.21 & 6.17 & 1.588 & 4.78 & 110.4 & 512.7 & Cylindrical \\
\hline & & 35.86 & 65.81 & 8.25 & 1.42 & 6.176 & 142.17 & 581.6 & Obovoid \\
\hline & & 34.17 & 43.16 & 5.61 & 1.125 & 3.22 & 75.67 & 605.3 & Ovoid \\
\hline EN & & 40.35 & 52.10 & 5.83 & 1.01 & 4.013 & 105.36 & 471.5 & Round \\
\hline K.1 & & 40.11 & 68.13 & 8.5 & 1.315 & 6.445 & 135.72 & 572.1 & Cylindrical \\
\hline K.1 & & 43.38 & 65.75 & 8.15 & 1.275 & 6.357 & 130.5 & 565.4 & Cylindrical \\
\hline & & 34.67 & 54.16 & 6.16 & 1.573 & 5.718 & 140.13 & 561.2 & Obovoid \\
\hline$A L$ & & 35.16 & 58.19 & 6.63 & 1.625 & 6.125 & 135.76 & 542.5 & Obovoid \\
\hline EUF & & 32.6 & 67.13 & 7.1 & 1.58 & 6.51 & 130.5 & 536.1 & Obovoid \\
\hline STA & -10 & 35.33 & 55.63 & 6.45 & 1.45 & 5.773 & 120.35 & 530.6 & Cylindrical \\
\hline PO. & & 33.46 & 61.22 & 6.83 & 1.23 & 5.51 & 120.13 & 572.1 & Obovoid \\
\hline & & 44.28 & 150.33 & 14.25 & 0.905 & 6.55 & 110.63 & 460.5 & Round \\
\hline $\mathrm{RO}$ & & 47.5 & 63.75 & 6.35 & 1.13 & 4.813 & 135.25 & 482.7 & Clyindrical \\
\hline $\mathrm{SM}$ & & 41.12 & 51.16 & 5.47 & 1.215 & 4.725 & 165.67 & 375.6 & Round \\
\hline GAF & & 23.17 & 18.25 & 5.16 & 0.256 & 0.41 & 15.32 & 410.4 & Ovoid \\
\hline $\mathrm{Me}$ & & 38.61 & 61.92 & 7.11 & 1.21 & 5.21 & 129.4 & 510.1 & \\
\hline SS & & 38.67 & 55.17 & 6.53 & 1.32 & 5.713 & 135.63 & 592.7 & Obovoid \\
\hline & $5 \%$ & 7.66 & 10.15 & 1.1 & 0.085 & 0.355 & 20.51 & 31.6 & \\
\hline & $1 \%$ & 10.18 & 13.5 & 1.46 & 0.113 & 0.473 & 27.28 & 42.03 & \\
\hline
\end{tabular}

SSB $^{*}$ : The commercial cultivar Super strain B as Check cv. (control) 


\section{Developing new Egyptian local lines of tomato (Solanum lycopersicum L.)}

\section{Components of variance:}

Estimations of coefficient of variation (C.V \%) components of variance, i.e. environmental variance $\left(\sigma^{2} e\right)$, genetic variance $\left(\sigma^{2} g\right)$, phenotypic variance $\left(\sigma^{2} p\right)$, geno- and phenotypic coefficient of variance (G.C.V\%, P.C.V \%), GCV/PCV ratio and broad sense heritability $\left(h^{2} b\right)$ for the studied traits are listed in Table 3. The variance varied from trait to another, since the coefficient of variation (C.V\%) ranged from $3.79 \%$ to $12.15 \%$. The highest variation among the selected lines was detected for number of days to $50 \%$ flowering and plant height since, they recorded the highest C.V\% values (12.15 and 10.04\%, respectively). Respecting the order, the low variation among the lines was observed for fruit firmness character, while it showed C.V $\%$ value of $3.79 \%$.

Regarding the genetic and phenotypic variances $\left(\sigma^{2} \mathrm{~g}\right.$ and $\sigma^{2} \mathrm{p}$ ), estimated $\sigma^{2} \mathrm{~g}$ vs $\sigma^{2} p$ for the studied traits were 50.65 vs 72.65 for the character of days to $50 \%$ flowering, 154.78 vs 193.42 for plant height 2.66 vs 3.11 for number of branches, 0.041 vs 0.044 for early yield, 0.904 vs 0.952 for total yield, 460.98 vs 618.72 for average fruit weight and 1149.5 vs 1523.96 for fruit firmness. In this respect, the studied traits showed low values of difference between phenotypic and genotypic variance, indicating that, large portion of the phenotypic variance $\sigma^{2} p$ was due to the genetic variance $\sigma^{2} \mathrm{~g}$ and the observed significant differences among the selected lines are genetically controlled.

Table (3): Coefficient of variance (C.V \%), component of variance $\left(\sigma^{2} g\right.$ and $\left.\sigma^{2} p\right)$, genoand phenotypic coefficient of variation (G.C.V and P.C.V \%) and broad sense $\left(\mathrm{H}^{2} \mathrm{BS}\right)$ heritability for studied traits.

\begin{tabular}{|c|c|c|c|c|c|c|c|}
\hline Genotypes & $\begin{array}{c}\text { Days of } \\
50 \% \\
\text { flowering }\end{array}$ & $\begin{array}{c}\text { Plant } \\
\text { height } \\
(\mathrm{cm})\end{array}$ & $\begin{array}{c}\text { Number of } \\
\text { branches/ } \\
\text { plant }\end{array}$ & $\begin{array}{c}\text { Early } \\
\text { yield } \\
\text { (kg/ } \\
\text { plant) }\end{array}$ & $\begin{array}{c}\text { Total yield } \\
\text { (kg/plant) }\end{array}$ & $\begin{array}{c}\text { Average } \\
\text { fruit } \\
\text { weight } \\
(\mathrm{g})\end{array}$ & $\begin{array}{c}\text { Fruit } \\
\text { firmness } \\
(\mathrm{g} / \mathrm{cm} .)\end{array}$ \\
\hline $\mathrm{C} . \mathrm{V} \%$ & 12.15 & 10.04 & 9.43 & 4.51 & 4.21 & 9.71 & 3.79 \\
\hline$\sigma^{2} \mathrm{e}$ & 22 & 38.64 & 0.45 & 0.003 & 0.048 & 157.74 & 374.46 \\
\hline$\sigma^{2} \mathrm{~g}$ & 50.65 & 154.78 & 2.66 & 0.041 & 0.904 & 460.98 & 1149.5 \\
\hline$\sigma^{2} \mathrm{p}$ & 72.65 & 193.42 & 3.11 & 0.044 & 0.952 & 618.72 & 1523.96 \\
\hline $\mathrm{H}^{2} \mathrm{BS}$ & 0.70 & 0.8 & 0.86 & 0.93 & 0.94 & 0.75 & 0.75 \\
\hline G.C.V\% & 18.43 & 20.09 & 22.94 & 16.67 & 18.25 & 16.59 & 6.65 \\
\hline P.C.V\% & 22.08 & 22.46 & 24.8 & 16.26 & 18.53 & 19.22 & 7.65 \\
\hline gcv/pcv \% & 83 & 89 & 92 & 96 & 98 & 86 & 87 \\
\hline
\end{tabular}


For geno- and phenotypic coefficient of variation ( GCV\% and PCV\% ), estimated GCV \% vs PCV \% values for the studied traits ( table 3 ) were, 18.43 vs 22.08 for days to $50 \%$ flowering, 20.09 vs $22.46 \%$ for plant height, 22.94 vs 24.80 for number of branches , 16.67 vs 17.26 for early yield, 18.25 vs 18.53 for total yield, 16.59 vs 19.22 for average fruit weight and 6.65 vs 7.65 for fruit firmness. Also, obtained broad sense heritability $\left(\mathrm{H}^{2} \mathrm{BS}\right)$ values for the traits ranged from 0.70 to 0.94 , suggesting high values of heritability. Likewise, the GCV/PCV ratios showed high values, since ranged from 83 to $97 \%$. Generally, smaller are the values of differences between pheno and genotypic coefficient of variations, the lesser will be the environmental effect on the character. In another term, the large portion of phenotypic variance $\left(\sigma^{2} p\right)$ was due to the genetic variance and significant differences among the studied breeding lines are genetically controlled with a small environmental effects. Therefore, these characters could be improved through selection based on phenotypic observations and selection for such cases would be effective in achieving superior lines through the early segregating generations in tomato. These results are in agreement with the findings of Asati et al., (2008), Anjum Ara et al., (2009), Suarma et al., (2009), Kansouh and Zakher (2011), and Ahirwar et al., (2013), who found a close correspondence between geno- and phenotypic coefficient of variation with high broad sense heritability values for the same traits studied in tomato and suggested selection for improving these traits.

\section{REFERENCES}

Ahirwar, C.S., V. Bahardur and V. Prakash (2013). Genetic variability, heritability and correlation studies in tomato genotypes (Lyspersiocon esculentum Mill). International J. of Agric. Sci., 9 (1): 172 176.

Anjum, A., R. Narayan, N. Ahmed and S.H. Khan (2009). Genetic variability and selection parameters for yield and quality attributes in tomato. Indian J. of Hort., 66 (1): $73-78$.

Asati, B.S., N. Rai and A.K. Singh (2008). Genetic parameters study for yield and quality traits in tomato. The Asian $\mathrm{J}$. of Hort., 3 (2): 222-225.

Berry, S.Z. and M. Rafique Uddin (1988). Effect of high temperature on fruit set in tomato cultivars and select germplasm. HortSci. 23 (3); 606-608.

Bhatt, R.P., V.R. Biswas and N. Kumar (2001). Heterosis, combining ability and genetics for vitamin $\mathrm{C}$, total soluble solids and yield in tomato (Lycopersicon esculentum) at $1700 \mathrm{~m}$ altitude. J. Agri. Sci., Cambridge 137: 71 -75.

Hannan, M.M., M.K. Buswas, M.B. Ahmed, M. Hossain and R. Islam (2007). Combining ability analysis of yield and yield component in tomato (Lycopersicon esculentum Mill). Turkish J. of Bot. 31 (6): $559-563$.

Holiday, R. (1976). The efficiency of solar energy conversion by the whole crop. Food Prod. and Cons., PP.127-146.

Islam, M.S., S. Ahmed and M.A. Hoque (2011). Selection in segregation population of tomato (Solanum Lycopersicum) for growth, yield and virus resistance. Bangladesh J. of Agri. Res., 36 (3): 507 -512 (CA. CAB Abst. 2012 ; AN.20123015725).

Kansouh, A.M. (2002). Developing high yielding lines of tomato (Lycopersicon esculentum Mill) by selection. $2^{\text {nd }}$ Inter. Conf. Hort. Sci., 10-12 sept. 2002, Kafr El-sheikh, Tanta Univ., Egypt, 28: 152 164.

Kansouh, A.M. (2013). Genetic analysis for some tomato traits. Egypt. J. of Appl. Sci., 28 (11): 732- 743.

Kansouh, A.M. (2014). Breeding new local tomato hybrids at west-Delta region of Egypt. J. Plant Production, Mansoura Univ., vol.5 (8): 1455 -1469.

Kansouh, A.M. and A.G. Zakher (2011). Gene action and combining ability in tomato by line $x$ tester analysis. $J$. of 


\section{Developing new Egyptian local lines of tomato (Solanum lycopersicum L.)}

Plant Production, Mansoura Univ., 2 (2) $213-227$.

Metwally, E., A. EL-Zawily, M. Hassan and O. Zanata (1996). Inheritance of fruit set and yield of tomato under high temperature conditions in Egypt. $1^{\text {st }}$ Egypt-Hung-hort.conf., 1:112-122.

Patel, S.A., B. Kshirsagar, A.V. Attar and M.N. Bhalekar (2013). Study on genetic variability, heritability and genetic advance in tomato. International $\mathrm{J}$. of PI.Sci. (Muzaffarnagar); 8(1): 45 - 47. (CA. CAB Abst. 2013; AN. 20133276978.

Saeed, A.S.C., A.A. Khan, B. Sadia and L.A. Khan (2008). Analysis of combining ability for yield, yield component and quality characters in tomato (Lycopersicon esculentum Mill). J.Agric. Res., 46 (4): 325 - 332.

Salib, F.S. (2012). General and specific combining ability and genetic behavior of yield and some fruit characters of tomato under open field condition. Egypt. J. of Appl. Sci., 27 (6): 267 -282.

Sekhar, L., B.G. Parkash, P.M. Salimath, C.P. hiremath, O. Sridevi and A.A. Patil (2010). Implication of heterosis and combining ability among productive single cross hybrids in tomato. Electronic J. of PI. Breed., 1 (4): 707 -711.
Shahabuddin, A., A.K.M. Quamrussam and M.N. Uddin (2009). Combining ability estimates of tomato (Solanum lycopersicum) in late summer. SAARC J. Agri., 7 (1) 43 -55.

Singh, N.B., A.M. Devi, N.G. Singh, M.D. Singh, J.M. Laishram and T. Bhagirath (2007). Combining ability analysis for yield and its components in tomato (Lycopersicon esculentum. Mill) in Manipur valley. Environmental and Ecology, 25 (1): 1-4.

Singh, R.K. and B.D. Chadhary (1995). Biometrical methods in quantitative genetic analysis. Kalyani Publisher, New Delhi 110002, India.

Suarum , J.P., A.K. Singh, S. Kumar and Sanjeev Kumar in (2009). Identification of traits for ideotype selection in tomato (Lyscopersicon esculentum Mill.). Mysore J.Agric. Sci., (2): 222-226.

Thakur, A.K. and U.K. Kohli (2005). Studies on genetic of shelf- life in tomato. Indian J. Hort., 62 (2): 163 -167.

UPOV (1992). International union for the protection of new varieties of plant. UPOV Guide line of tomato TG/ 44/7., 156 P.21. 


\section{إستنباط سلالات جديدة مصرية من الطماطم محلياً}

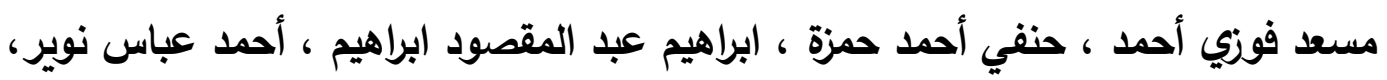

\section{مصطفي الانصاري}

قسم البيوتكنولوجيا النباتية - معهد بحوث الهندة الوراثية والتكنولوجيا الحيوية -جامعة مدينة السادات

الملخص العربي

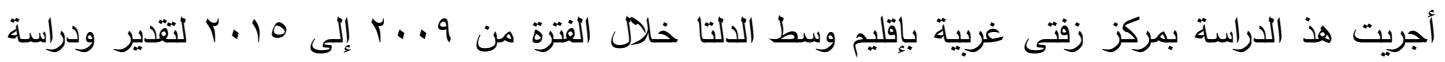

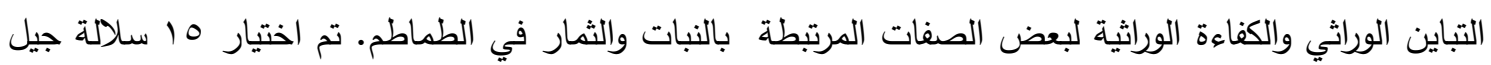
سابع منتجة من ؛ عشائر جيل ثاني بعد 7 أجيال انتخابية.

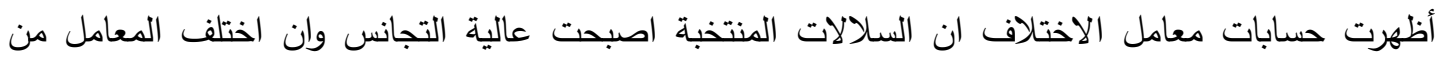
صفة لأخرى وأظهرت الدراسة وجود تتوع وفروق معنوية بين السلالات وبعضها في كل الصفات المدروسة. تعتبر

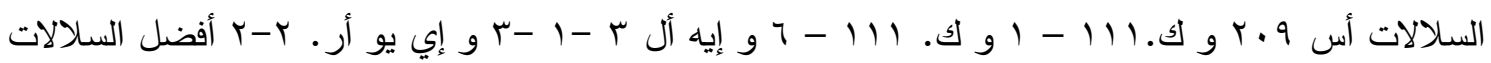
في الصفات المحصولية والثمرية ويمكن استخدامها في برامج تربية لإنتاج هجن محلية.

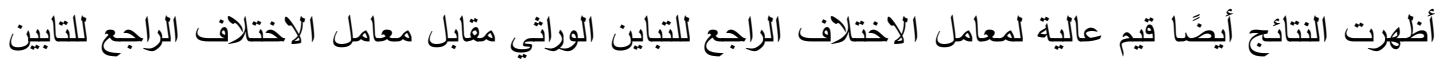

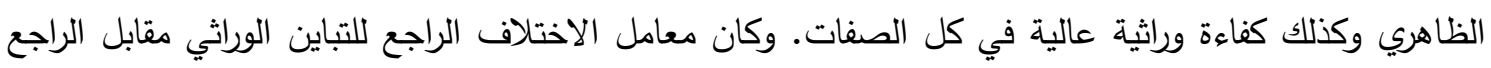

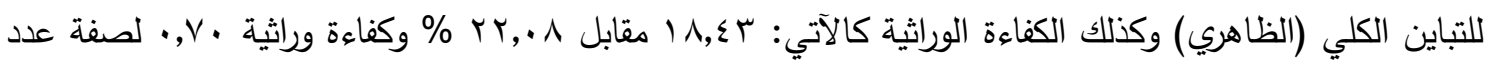

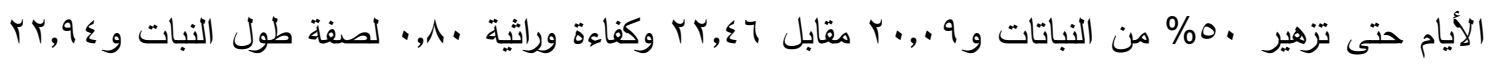

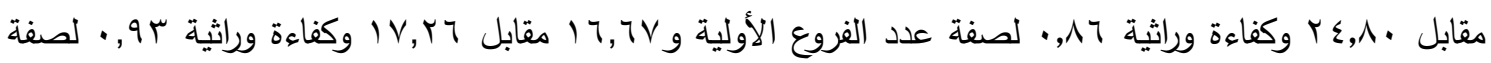

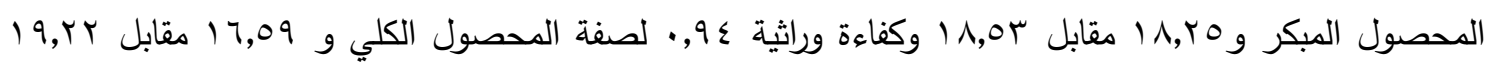

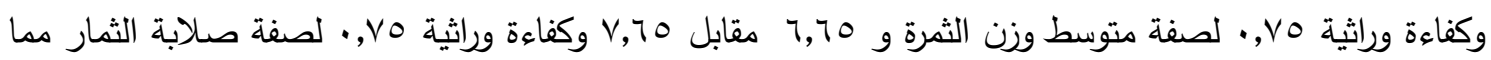
يدل على صغر تأثير البيئة على هذه الصفات وأن الجزه الأكبر من المكون الكلي (الظاهري) للتباين يرجع إلى ونى المكونات الوراثية لعوامل الإضافة مما يجعل تحسين هذه الصفات ممكن خلال برامج الانتخاب. 
